\title{
PENGEMBANGAN MODEL PEMBELAJARAN CO-OP CO-OP BERBANTU TEKNOLOGI INFORMASI DAN KOMUNIKASI (TIK) PADA MATA PELAJARAN EKONOMI
}

\author{
Manoto Togatorop \\ notolpmiccc@gmail.com \\ Program Studi S1 Pendidikan Ekonomi \\ FKIP - Universitas Kristen Satya Wacana
}

\begin{abstract}
This study aims to develop co-op co-op learning model assisted Inforamsi and Communication Technology (ICT) on Economic subjects. Type of research used in this research is research development (Research and Development). The development model used is 10 steps from Borg and Gall that are limited to five steps, namely the identification of potentials and problems; data collection or information; product design; validation; and revisions. The results show that co-op co-op ICT-assisted learning model consists of five main steps, namely preparation, development, implementation, evaluation, and revision. Particularly in the implementation step, there are nine steps in the co-op co-op ICT-supported learning. This model has been declared eligible by material validators and media validators. Therefore, it is suggested to further research to test this model empirically with action research or experimental research.
\end{abstract}

Keywords: co-op co-op, information and communication technology, economic subject

\section{PENDAHULUAN}

Salah satu bidang kehidupan yang dipengaruhi oleh teknologi dalam pengembangannya adalah pendidikan. Hal ini dapat ditinjau dari berbagai aplikasi yang digunakan dalam penyampaian materi pembelajaran guna mendukung adanya pemindahan pengetahuan secara efektif melalui video, tape recorder, aplikasi pengolah kata, aplikasi pengolah gambar, dan komputer. Teknologi Informasi dan Komunikasi (TIK) dalam bidang pendidikan menyebabkan terjadinya pergerakan informasi tanpa batas yang dapat dilakukan dengan cepat sehingga menyebabkan perubahan mendasar dan penyesuaian dalam hal cara mengajar guru, belajar murid, dan menajemen sekolah dari yang ada sebelumnya.
Perkembangan TIK saat ini sangat pesat dengan munculnya hardware dan software baru yang menarik dan mempermudah pengguna dalam berbagai keperluan. Penggunaan secara luas terjadi di dalam masyarakat termasuk para siswa dan guru, tetapi teknologi tersebut belum banyak digunakan dalam pembelajaran. Bentukbentuk TIK tersebut dapat memberikan dampak positif dalam dunia pendidikan khususnya saat berlangsung pembelajaran seperti pada saat persiapan, proses, dan evaluasi pembelajaran. Pada tahap persiapan pembelajaran, guru dapat mempersiapkan materi pelajaran dengan mengakses dari web. Selain itu, guru dapat mempersiapkan konten pembelajaran yang menarik untuk diajarkan. Pada tahap proses pembelajaran, guru dapat menggunakan perangkat yang digunakan saat 
menyampaikan materi seperti MS Power Point. Begitu juga dengan siswa dapat mengerjakan tugas dengan menggunakan $e$ learning. Pada tahap evaluasi pembelajaran, guru dapat menggunakan MS Excel untuk menyimpan data-data nilai siswa dan mencari rerata nilai akhir siswa.

Pembelajaran sebagai sistem terdiri dari input, proses, dan output. Tugas utama guru dalam sistem tersebut adalah menyelenggarakan pembelajaran (yang berarti mengarah pada proses) sedangkan input adalah komponen yang tidak dapat dikendalikan oleh guru. Dalam hal input, guru tidak memiliki kapasitas untuk memilih siapa saja peserta didik yang akan diajarnya sedangkan dalam hal output, guru juga tidak diperkenankan menentukan output dari seorang siswa secara subjektif. Dalam hal ini, output dapat ditingkatkan melalui penyelenggaraan proses pembelajaran yang lebih baik.

Pembelajaran merupakan hasil sinergi dari tiga komponen utama, yaitu siswa, kompetensi guru, dan fasilitas pembelajaran. Ketiga komponen tersebut pada akhirnya bermuara pada proses dan model pembelajaran. Ketersediaan TIK sebagai fasilitas belajar akan mempermudah guru untuk meningkatkan kompetensinya sebagai pengajar dan membantu saat mengajar. Hal tersebut akan berdampak pada siswa untuk lebih mudah memahami materi yang disampaikan guru baik di dalam kelas maupun di luar kelas atau pada saat siswa menyelesaikan tugastugas yang diberikan guru. Seperti yang dikatakan Suryani (2015), bahwa TIK mampu mendukung dan mempermudah proses belajar mengajar serta penyampaian dan penyajian materi akan lebih menarik dan menyenangkan sehingga menimbulkan minat siswa dan memberikan banyak manfaat dalam pendidikan.
Sistem pembelajaran dengan TIK sebagai nilai tambah dapat diterapkan di berbagai disiplin keilmuan seperti bahasa, matematika, dan ekonomi. Disiplin keilmuan tersebut tentunya memiliki kebutuhankebutuhan yang perlu difasilitasi dengan adanya fasilitas bantuan pembelajaran seperti TIK. Pembelajaran ekonomi membutuhkan informasi tentang kondisi perekonomian agar teori yang ada dalam buku teks mendapatkan referensi dalam kehidupan nyata. Dengan adanya informasi tentang kondisi perekonomian yang relevan maka pembelajaran ekonomi menjadi lebih kontekstual dan bermakna bagi siswa. Kemajuan TIK telah mendorong terjadinya banyak perubahan dalam pengembangan media pembelajaran ekonomi. Siswa dalam belajar ekonomi tidak hanya bergantung pada pengetahuan yang diajarkan, tetapi juga bergantung pada proses pengetahuan tersebut diajarkan atau cara siswa itu belajar.

Menurut Permendikbud No. 21 Tahun 2016 Tentang Standar Isi/Standar Kompetensi Dasar SMA, mata pelajaran ekonomi bertujuan agar siswa memiliki berbagai kemampuan. Pertama, dengan belajar ekonomi siswa mampu memahami sejumlah konsep ekonomi untuk mengetahui dan mengerti peristiwa dan masalah ekonomi dalam kehidupan sehari-hari, terutama yang terjadi di lingkungan setingkat individu/rumah tangga, masyarakat dan negara. Kedua, dengan belajar ekonomi, siswa akan dibekali sejumlah konsep ekonomi yang diperlukan untuk mendalami ilmu ekonomi pada jenjang selanjutnya. Kemudian, siswa akan dibekali nilai-nilai serta etika ekonomi dan memiliki jiwa wirausaha. Ketiga, dengan belajar ekonomi siswa mampu meningkatkan kemampuan berkompetensi dan bekerjasama dalam masyarakat yang 
majemuk, baik dalam skala nasional maupun skala internasional.

Tujuan pembelajaran tersebut memberikan bekal kemampuan dasar yang bermakna bagi kehidupan siswa di lingkungan masyarakat. Pembelajaran ekonomi pada dasarnya juga membahas hubungan antara manusia dengan lingkungannya. Lingkungan yang dimaksud adalah lingkungan dimana siswa tersebut tinggal dan berkembang menjadi bagian dari masyarakat. Oleh karena itu sudah semestinya pembelajaran ekonomi ini dilakukan atau diarahkan pada bentuk pembelajaran kontekstual yang mana hal ini berguna sebagai upaya mengaitkan isi mata pelajaran ekonomi dengan dunia nyata.

Tujuan tersebut harus didukung dengan kesiapan guru dalam menyampaikan materi pelajaran ekonomi. Persiapan tersebut meliputi silabus, Rencana Proses Pembelajaran (RPP), tugas-tugas, sistem penilaian, dan aspek lainnya yang menunjang pembelajaran ekonomi. Guru harus menggunakan media dan model pembelajaran yang menarik supaya siswa aktif dan antusias dalam mengikuti pembelajaran. Hal itu akan menghasilkan hubungan timbal balik yang baik antara siswa dan guru, keadaan kelas juga akan kondusif, dan pembelajaran ekonomi menjadi menyenangkan.

Kenyataan di lapangan menunjukan kondisi-kondisi yang tidak sesuai dengan idealisme yang telah dikemukakan tersebut. Kenyataan ini diperoleh melalui observasi pendahuluan yang dilakukan pada pembelajaran di beberapa sekolah SMA dan SMK kota Salatiga. Data observasi ini didukung dengan wawancara yang dilakukan pada guru ekonomi yang mengajar pada sekolah-sekolah tersebut.

Antusiasme siswa SMA dan SMK untuk belajar mata pelajaran ekonomi masih rendah. Sementara itu, mata pelajaran ekonomi dijadikan standar kelulusan sekolah dan salah satu mata pelajaran yang diujikan kepada siswa sebagai kreteria untuk meneruskan ke jenjang pendidikan yang lebih tinggi. Masalah lainnya adalah kurangnya partisipasi siswa saat proses pembelajaran, ketergantungan siswa pada penjelasan guru, kurangnya keberanian siswa dalam bertanya, dan siswa cenderung hanya menerima materi yang disampaikan guru. Hal ini akan mengakibatkan siswa tidak bisa mengikuti pembelajaran dengan baik, siswa tidak mampu menyelesaikan tugas dengan baik yang akan berdampak pada hasil belajar siswa menjadi rendah. Selain itu, dalam kehidupan sehari-hari siswa tidak mampu mengelola keuangan pribadi dan tidak mendapat informasi keadaan pereknomian terbaru.

$\begin{array}{ccc}\text { Hal tersebut didukung } & \text { karena } \\ \text { kurangnya } & \text { keterampilan guru dalam }\end{array}$ mengembangkan pendekatan dan model pembelajaran sehingga fokus pembelajaran hanya terpusat pada guru. Selain itu, sering ditemukan guru-guru ekonomi yang kurang menghubungkan materi pelajaran dengan kenyataan praktis dan keterkaitannya dengan ilmu-ilmu lain dalam mengeksplorasi bahan pembelajaran. Ditambah lagi dengan situasi dan kondisi belajar yang tidak nyaman dan kurang variatif, seperti penggunaan metode ceramah yang kerap digunakan guru, minimnya penggunaan media, dan sebagian besar para guru cenderung menggunakan model konvensional.

Kertiyasa (2013) juga menyatakan di dalam hasil penelitiannya bahwa permasalahan dalam menyampaikan materi pembelajaran ekonomi dari sisi guru adalah guru kesulitan untuk mencari media yang cocok digunakan dalam pembelajaran ekonomi dan masih ada sekolah yang memiliki LCD dengan jumlah 
terbatas. Permasalahan dari siswa adalah masih banyak siswa yang tidak memiki buku ajar ekonomi, banyak siswa dengan karakteristik kemampuan rata-rata menengah ke bawah, dan siswa kelas IPS ternyata masih menjadi second class hampir di semua sekolah.

Hasil penelitian tersebut didukung dengan pendapat Siahaan (2009: 14) yang menyatakan bahwa: (1) para guru belum dipersiapkan dengan baik untuk memiliki kesiapan dalam memanfaatkan peralatan/ fasilitas TIK secara optimal bagi kepentingan kegiatan pembelajaran; (2) para guru juga tidak dibekali dengan pengetahuan dan keterampilan yang memadai di bidang pengembangan bahan-bahan belajar yang dapat disajikan melalui fasilitas/ peralatan TIK yang telah diadakan sekolah; (3) para guru tidak mendapatkan appresiasi atas usaha atau kerja ekstra yang telah mereka lakukan dalam mengoptimalkan pemanfaatan fasilitas/ peralatan TIK yang tersedia di sekolah; dan (4) kurangnya perhatian untuk melakukan perawatan atau pemeliharaan fasilitas/ peralatan TIK yang telah dimiliki sekolah (enerjik dalam membangun atau mengadakan tetapi lemah dalam melakukan perawatan/ pemeliharaan).

Jika hal tersebut dibiarkan terusmenerus maka akan menimbulkan masalah baru yaitu semakin rendahnya minat siswa untuk belajar ekonomi. Selain itu juga, kualitas guru akan semakin merosot karena tidak adanya keinginan untuk belajar menggunakan teknologi dan tidak adanya pembekalan penggunaan media pembelajaran ekonomi. Salah satu solusi yang diberikan peneliti untuk menyelesaikan masalah tersebut adalah dengan mengembangkan model pembelajaran co-op co-op berbantu TIK, karena TIK diduga mampu membuat proses pembelajaran ekonomi menajadi efisien dan efektif.

Pembelajaran Co-Op Co-Op merupakan salah satu proses yang dapat dilakukan oleh guru guna mencapai hasil belajar yang diharapkan. Pembelajaran ini merupakan salah satu model dalam pembelajaran kooperatif sebagaimana dikembangkan oleh Slavin. Model pembelajaran ini dapat diterapkan dalam berbagai mata pelajaran maupun karakter peserta didik, dengan syarat bahwa peserta didik dalam satu kelas berjumlah cukup banyak, sehingga guru dapat membentuk kelompok-kelompok belajar.

Berdasarkan uraian yang telah dipaparkan di atas, maka dapat ditarik sebuah rumusan masalah yaitu bagaimana pengembangan model pembelajaran Co-Op Co-Op berbantu teknologi informasi dan komunikasi pada mata pelajaran ekonomi? Model yang disajikan pada tulisan ini merupakan modifikasi dari model Co-Op Co-Op supaya dapat diimplementasikan dengan baik pada mata pelajaran ekonomi. Model Co-Op Co-Op original yang telah dikembangkan oleh Slavin dimodifikasi dengan cara integrasi dengan teknologi informasi dan komunikasi supaya diperoleh model baru yang diharapkan akan lebih efektif dalam memperbaiki proses pembelajaran.

\section{KAJIAN TEORI}

\section{Model Pembelajaran Co-Op Co-Op}

Menurut Slavin (2009: 229), model pembelajaran co-op co-op adalah model pembelajaran yang menempatkan tim dalam kooperasi antara satu dengan yang lainnya untuk mempelajari sebuah topik di kelas. Adapun langkah-langkah model pembelajaran tipe co-op co-op menurut Slavin (2009: 229235) adalah sebagai berikut: 
1. Diskusi kelas terpusat kepada siswa. Pada awal pembelajaran, guru mendorong para siwa untuk menemukan dan mengekspresikan ketertarikan mereka terhadap subyek yang akan dicakupi. Tujuan langkah pertama ini adalah untuk dapat meningkatkan keterlibatan siswa dalam pembelajaran dengan memancing rasa keingintahuan mereka.

2. Menyeleksi tim pembelajaran siswa dan pembentukan tim. Guru mengatur para siswa ke dalam tim yang terdiri 4-5 orang.

3. Seleksi topik tim. Guru membiarkan siswa memilih topik untuk tim siswa. Guru hendaknya mendorong para siswa untuk mendiskuaikan berbagai macam topik diantara anggota tim supaya siswa dapat memastikan topik yang paling banyak menarik perhatian anggota tim.

4. Pemilihan topik kecil. Setelah kelas terbagi ke dalam beberapa kelompok tim, tiap tim membagi topiknya untuk membuat pembagian tugas diantara anggota tim. Anggota tim didorong untuk saling berbagai referensi dan bahan pelajaran, dan tiap topik kecil harus memberikan kontribusi yang unik bagi usaha tim.

5. Persiapan topik kecil. Setelah para siswa membagi topik tim siswa menjadi topiktopik kecil, para siswa akan bekerja secara individual. Masingmasing siswa tahu akan tanggung jawabnya terhadap topik kecil dan bahwa kelompok tersebut tergantung pada kelompok tim untuk menemukan aspek penting dari usaha yang dilakukan tim.

6. Presentasi topik kecil. Setelah para siswa menyelesaikan kerja individual, para siswa mempresentasikan topik kecil kepada teman satu kelompoknya. Presentasi topik kecil di dalam tim haruslah bersifat formal, yaitu tiap anggota tim diberikan waktu khusus dan berdiri ketika mempresentasikan topik kecilnya. Presentasi dan diskusi topik kecil di dalam tim dilakukan dengan cara yang dapat membuat semua teman satu tim memperoleh semua pengetahuan dan pengalaman yang dilakukan oleh masing-masing anggota tim. Selama presentasi topik kecil, pembagian tugas di dalam tim bisa didorong supaya ada satu anggota tim yang mencatat, yang lainnya mengkritik, yang lain lagi memberi dukungan, dan yang lain lagi memeriksa poin-poin yang mencapai titik temu dan yang tidak dari informasi yang dipresentasikan.

7. Persiapan presentasi tim. Diskusi mengenai bentuk presentasi tim harus mengikuti sintesis materi topik kecil. Bentuk presentasi tersebut haruslah ditentukan berdasarkan konten materinya. Penggunaan papan tulis, PPT, dan media-media audio visual.

8. Presentasi tim. Selama waktu presentasinya, tim memegang kendali kelas. Semua anggota tim bertanggungjawab pada bagaimana waktu, ruang, dan bahan-bahan yang ada di kelas digunakan selama presentasi mereka; mereka sangat dianjurkan untuk menggunakan sepenuhnya fasilitas-fasilitas yang ada di dalam kelas. Dalam presentasi tim, mereka boleh saja memasukkan sebuah periode tanya jawab dan waktu untuk memberikan komentar dan umpan balik.

9. Evaluasi. Evaluasi dilakukan pada tiga tingkatan: (1) pada saat presentasi tim dievaluasi oleh kelas; (2) kontribusi individual terhadap usaha tim untuk dievaluasi oleh teman satu tim; dan (3) pengulangan kembali materi atau presentasi topik kecil oleh tiap siswa dievaluasi oleh sesama siswa. 


\section{Teknologi Informasi dan Komunikasi}

Sholikha (2015), menyatakan bahwa, teknologi informasi adalah perpaduan antara teknologi komputer dengan informasi, dimana informasi tersebut diolah dengan menggunakan teknologi komputer sehingga menghasilkan sebuah teknologi yang mampu memberikan informasi dan kemudahankemudahan lainnya bagi para pemakainya. Selanjutnya Ismaniati (2010), menyatakan bahwa, "TIK merupakan teknologi yang diperlukan untuk memproses informasi, terutama penggunaan komputer elektronik dan piranti lunak komputer, yang ditujukan untuk mengolah, menyimpan, melindungi, mentransmisikan, dan mencari informasi dari mana saja dan kapan saja."

Daniel (2002: 13), menyatakan bahwa, "information and communication technology defined as the combination of informatics technology with other, related technologies, specifically communication technology will be used, applied, and integrated in activities of working and learning on the basis of conceptual understanding and methods of informatics." TIK didefinisikan sebagai kombinasi teknologi informatika dengan teknologi terkait lainnya khususnya teknologi komunikasi yang akan digunakan, diterapkan, dan diintegrasikan dalam kegiatan kerja dan pembelajaran berdasarkan pemahaman konseptual dan metode informatika.

Sedangkan Celebic dan Dario (2011: 2), menyatakan bahwa, "information and communication technology is the foundation of economy and a driving force of social changes encompasses all of the technology that use to collect, process, protect, and store information. It refers to hardware, software (computer programs), and computer networks with an Internet connection and a computing device." TIK merupakan pondasi ekonomi dan pendorong perubahan sosial yang mencakup semua teknologi yang digunakan untuk mengumpulkan, memproses, melindungi, dan menyimpan informasi. Ini mengacu pada perangkat keras, perangkat lunak (program komputer), dan jaringan komputer dengan koneksi internet dan perangkat komputasi.

Laudon (2007) menambahkan bahwa, "technological and engineering disciplines and the management techniques used in information handling, processing and disseminating; their applications; computers, networking and communication and their integration with men and machines; and associated social, economic and cultural matter." TIK merupakan bagian-bagian rekayasa teknologi dan teknik-teknik pengelolaan yang digunakan dalam penggunaan, pemrosesan dan penyebaran informasi; penerapannya seperti dalam penggunaan komputer, komunikasi dan jaringan, serta integrasinya dengan manusa dan mesin; dan menyatukan unsur-unsur sosial, ekonomi dan budaya.

Banyak hal yang telah dilakukan pemangku kebijakan pendidikan untuk meningkatkan mutu pendidikan, khususnya mutu pembelajaran ekonomi agar manfaat penggunaan teknologi informasi dan komunikasi bisa berdampak pada guru dan siswa. Manfaat TIK menurut Sihaan (2009: 19-21) adalah: Pertama, TIK berfungsi sebagai gudang ilmu pengetahuan, dapat berupa referensi berbagai ilmu pengetahuan yang tersedia dan dapat diakses melalui fasilitas TIK, pengelolaan pengetahuan, jaringan pakar, jaringan antara institusi pendidikan, sumber pengembangan materi ajar, dan wahana pengembangan kurikulum. Kedua, fungsi TIK sebagai alat bantu pembelajaran dapat berupa alat bantu mengajar bagi guru berupa animasi 
peristiwa, alat uji siswa, sumber referensi ajar, dan evaluasi kinerja; alat bantu belajar bagi siswa berupa buku interaktif, untuk belajar mandiri, latihan soal, dan media ilustrasi; serta alat bantu interaksi antara guru dengan siswa berupa komunikasi guru-siswa, simulai kasus, dan alat peraga visual. Ketiga, fungsi TIK sebagai fasilitas pendidikan di sekolah dapat berupa pojok internet, perpustakaan digital, kelas virtual, lab multimedia, dan papan elektronik. Menurut Krisnadi (2009), selain fungsinya sebagai alat bantu pemecahan masalah manusia, media TIK juga dapat dimanfaatkan untuk mendukung proses pembelajaran yang dipercaya dapat: (1) meningkatkan kualitas pembelajaran; (2) memperluas akses terhadap pendidikan dan pembelajaran; (3) mengurangi biaya pendidikan; (4) menjawab keharusan berpartisipasi dalam TIK; dan (5) mengembangkan keterampilan TIK yang diperlukan siswa ketika bekerja dan dalam kehidupannya nanti.

TIK mencakup semua teknologi yang dapat digunakan untuk menyimpan, mengolah, menampilkan, dan menyampaikan informasi dalam proses komunikasi. Siahaan (2009: 11), menyatakan bahwa TIK terdiri dari hardware dan software. Hardware atau perangkat keras adalah segala sesuatu peralatan teknologi yang berupa fisik. Cirinya yang paling mudah adalah terlihat dan bisa disentuh. Sedangkan software atau perangkat lunak adalah sistem yang dapat menjalankan atau yang berjalan dalam perangkat keras tersebut. Software dapat berupa operating system, aplikasi, ataupun konten. Berdasarkan pemahaman konsep TIK tersebut berbagai jenis perangkat TIK yang dapat digunakan untuk kepentingan pendidikan dan pembelajaran menurut Siahaan sebagaimana terlihat pada Gambar 1.

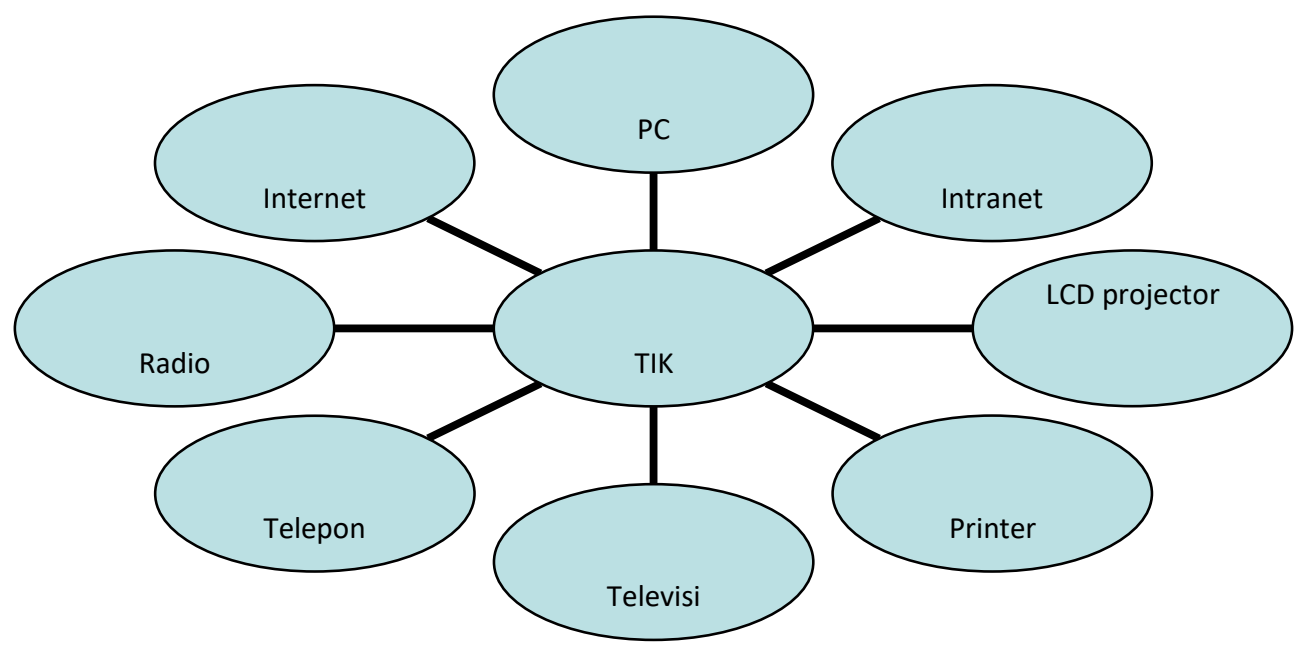

Gambar 1. Jenis-Jenis Teknologi Informasi dan Komunikasi

(Siahaan, 2009: 11)

Berdasarakan uraian di atas dapat disintesiskan bahwa teknologi inforamsi dan komunikasi adalah kombinasi teknologi informatika dengan teknologi komunikasi yang mengacu pada perangkat keras, perangkat lunak, dan jaringan komputer dengan koneksi internet dan perangkat komputasi. Dengan indikator (1) mengintegrasikan manusia dengan mesin serta menyatukan unsur-unsur sosial, ekonomi, dan budaya; (2) ditujukan untuk mencari, mengolah, menyimpan, melindungi, dan mentransmisikan informasi; (3) digunakan, diterapkan, dan diintegrasikan dalam kegiatan kerja dan 
pembelajaran berdasarkan pemahaman konseptual dan metode informatika.

\section{Mata Pelajaran Ekonomi}

Pembelajaran ekonomi merupakan ilmu yang mempelajari perilaku manusia dalam memilih dan menciptakan kemakmuran. Hal tersebut dipelajari melalui mata pelajaran ekonomi yang ada di SMA sederajat dan SMP sederajat (IPS Ekonomi). Menurut Anggia (2015), mata pelajaran ekonomi merupakan bagian dari mata pelajaran di sekolah yang mempelajari perilaku individu dan masyarakat dalam usaha memenuhi kebutuhan hidupnya yang tak terbatas dengan alat pemenuhan kebutuhan yang terbatas jumlahnya. Sedangkan menurut Novia (2012), mata pelajaran ekonomi dapat diartikan sebagai mata pelajaran yang diajarkan di sekolah yang mempelajari usaha manusia memenuhi kebutuhan.

Materi yang dibahas di mata pelajaran ekonomi adalah materi-materi ilmu ekonomi. Menurut Winarno dan Ismaya (2007: 177), ilmu ekonomi merupakan ilmu yang mempelajari asas-asas produksi, distribusi dan pemakaian barang-barang serta kekayaan, seperti keuangan, perindustrian, dan perdagangan; ilmu yang mempelajari usahausaha manusia untuk memenuhi kebutuhannya. Sedangkan Budimansyah (2003: 1), menyatakan bahwa, "ilmu ekonomi merupakan ilmu atau seni tentang upaya manusia untuk memenuhi kebutuhan hidupnya yang banyak, bervariasi dan berkembang dengan sumber daya yang ada melalui pilihan kegiatan produksi, konsumsi, dan distribusi."

Terakhir pendapat dari Samuelson (Sukwiaty, dkk, 2009: 120), yang menyatakan bahwa, "ilmu ekonomi sebagai suatu studi tentang perilaku orang dan masyarakat dalam memilih cara menggunakan sumber daya yang langka dan memiliki beberapa alternatif penggunaan, dalam rangka memproduksi berbagai komoditas, untuk kemudian menyalurkannya, baik saat ini maupun di masa depan kepada berbagai individu dan kelompok yang ada dalam suatu masyarakat."

Di dalam KTSP, pembelajaran ekonomi mencakup perilaku ekonomi dan kesejahteraan yang berkaitan dengan masalah ekonomi yang terjadi di lingkungan kehidupan terdekat hingga lingkungan terjauh yang meliputi perekonomian, ketergantungan, spesialisasi dan pembagian kerja, perkoperasian, kewirausahaan, akuntansi dan manajemen, keuangan negara, dan lain sebagainya. Tujuan Ilmu Ekonomi menurut Abdullah (1992: 7) yaitu, mencari pengertian tentang hubungan peristiwa-peristiwa ekonomi baik yang berupa hubungan kausal maupun fungsional, menguasai masalah-masalah ekonomi yang dihadapi oleh masyarakat.

Luasnya ilmu ekonomi membuat kompetensi inti dan kompetensi dasar pada pembelajaran ekonomi di SMA/MA dibatasi dan difokuskan pada fenomena empirik ekonomi yang ada disekitar siswa, sehingga siswa dapat menangkap konsep ilmu ekonomi dengan lebih baik dan rasional. Berikut ini karakteristik bidang studi ekonomi menurut UU No. 20 Tahun 2003 Tentang Sisdiknas yaitu: (1) mata pelajaran ekonomi berangkat dari fakta atau gejala ekonomi yang nyata; (2) mata pelajaran ekonomi mengembangkan teori-teori untuk menjelaskan fakta secara rasional; (3) analisis yang digunakan dalam ilmu ekonomi adalah metode pemecahan masalah; (4) inti dari ilmu ekonomi adalah memilih alternatif yang terbaik; dan (5) lahirnya ilmu ekonomi karena adanya kelangkaan sumber pemuas kebutuhan manusia. Sedangkan karakteristik pembela- 
jaran ekonomi menurut Novia (2012) adalah: (1) menggunakan peta konsep untuk mempermudah pengelompokan sub-sub materi; (2) sistem pencatatan materi yang bersifat perbedaan, dilakukan dengan menggunakan tabel, untuk memperjelas perbedaan subsub materi; (3) pembelajaran ekonomi membutuhkan ingatan untuk mempermudah pemahaman materi; (4) pembelajaran ekonomi menggunakan hitungan dengan beberapa pendekatan, dan menggunakan grafik ataupun diagram untuk menggambarkan tingkatan suatu kejadian atau peristiwa ekonomi.

Karakteristik pembelajaran ekonomi tidak terlepas dengan langkah-langkah pembelajaran ekonomi. Adapun langkahlangkah pembelajaran ekonomi menurut Dasim Budimansyah (2003: 25) sebagai berikut: (1) mengidentifikasi masalah ekonomi, artinya, melalui pembelajaran ekonomi para siswa harus dibina agar memiliki kecakapan untuk memecahkan masalah ekonomi yang terjadi di lingkungannya; (2) memilih masalah untuk kajian kelas, artinya, dalam hal ini guru memberi arahan agar masalah tidak keluar dari kajian materi pelajaran dengan tujuan agar siswa memperoleh pemahaman yang baik tentang masalah mana yang sebaiknya dipilih untuk bahan kajian di kelas; dan (3) mengumpulkan informasi tentang masalah yang akan dikaji, artinya, hal ini dapat dilakukan dengan cara mengidentifikasi sumber-sumber informasi. Sumber informasi misalnya, kantor penerbit surat kabar, kantor pemerintah daerah, kepolisian dan lingkungan sekitar. Sumber informasi dapat disesuaikan dengan masalah yang akan dikaji.

Berdasarakan uraian di atas dapat disintesiskan bahwa pembelajaran ekonomi adalah kegiatan mengorganisasikan ling- kungan yang ada di sekitar siswa agar mempunyai keterampilan hidup berekonomi. Dengan indikator: (1) mendorong untuk mempelajari perilaku individu dan masyarakat dalam usaha memenuhi kebutuhan hidupnya yang tak terbatas dengan alat pemenuhan kebutuhan yang terbatas; (2) menggunakan sumber daya yang langka dengan baik; (3) memiliki alternatif penggunaan; memproduksi berbagai komoditas kebutuhan manusia, dan (5) menyalurkannya baik pada saat ini maupun di masa yang akan datang.

\section{METODE PENELITIAN}

Jenis penelitian yang digunakan dalam penelitian ini adalah penelitian dan pengembangan atau Research and Development ( $\mathrm{R} \&$ D). Menurut Sugiyono (2010: 407), penelitian dan pengembangan adalah metode penelitian yang digunakan untuk menghasilkan produk tertentu dan menguji keefektifan produk tersebut. Peneliti melakukan penelitian dan pengembangan media pembelajaran ekonomi dengan menggunakan TIK. Tingkat kelayakan media pembelajaran ekonomi dengan menggunakan TIK tersebut diketahui melalui validasi oleh ahli materi dan ahli media.

Borg \& Gall dalam Sugiono (2010: 409-426) memaparkan sepuluh langkah pelaksanaan strategi penelitian dan pengembangan sebagai berikut:

1. Potensi dan masalah yang meliputi segala sesuatu yang bila didayagunakan akan memiliki nilai tambah

2. Pengumpulan data atau informasi yang meliputi pengukuran kebutuhan, studi literatur, penelitian dalam skala kecil, dan pertimbangan-pertimbangan dari segi nilai.

3. Desain produk, yaitu pengembangan bahan pembelajaran, proses pembelajaran, dan instrumen evaluasi. 
4. Validasi desain, merupakan proses kegiatan untuk menilai suatu rancangan produk secara rasional akan lebih efektif atau tidak dari yang lama. Validasi desain ini dilakukan oleh tenaga ahli yang sudah berpengalaman di bidangnya

5. Perbaikan desain, yaitu tahap untuk memperbaikai desain setelah diketahui kelemahannya dari tenaga ahli.

6. Uji coba produk, yaitu tahap pengamatan, wawancara, pengedaran angket, dan eksperimen.

7. Revisi produk, yaitu tahap menguji signifikansi antar kelompok yang diajar.

8. Uji coba pemakaian, yaitu penerapan dalam ruang lingkup lembaga yang lebih luas.

9. Revisi produk. Hal ini dilakukan jika pada saat uji coba pemakaian pada lembaga yang lebih luas terdapat kekurangan dan kelemahan.

10. Pembuatan produk masal, yaitu kerja sama dengan perusahaan untuk memperbanyak produk.

Prosedur penelitian yang dilakukan peneliti dalam pengembangan ini diadaptasi dari langkah-langkah pengembangan yang dikembangkan oleh Borg \& Gall tersebut. Penerapan langkah-langkah pegembangannya disesuaikan dengan kebutuhan peneliti. Mengingat keterbatasan waktu dan dana yang dimiliki oleh peneliti, maka langkah-langkah tersebut disederhanakan menjadi lima langkah pengembangan. Langkah pengembangan yang dilakukan oleh peneliti adalah:

1. Potensi dan masalah. Tahap ini telah dipaparkan pada bab pendahuluan bahwa kurangnya keterampilan guru dalam mengembangkan pendekatan dan model pembelajaran ekonomi serta antusiasme siswa SMA/SMK/MA untuk belajar mata pelajaran ekonomi yang masih rendah.
2. Pengumpulan data atau informasi.

Tahap pengumpulan data dilakukan untuk mengetahui kebutuhan pembelajaran di lapangan. Tahap pengumpulan data dilakukan dengan cara studi lapangan dan studi pustaka. Studi lapangan dilakukan untuk mengetahui kebutuhan sumber dan media pembelajaran ekonomi di SMA. Studi lapangan dilakukan dengan cara analisis kurikulum yang berlaku di sekolah, analisis tahap perkembangan siswa, dan analisis ketersediaan sumber dan media pembelajaran di lapangan sedangkan studi pustaka mengenai teori yang berhubungan dengan TIK dan pembelajaran ekonomi.

3. Desain produk. Tahap ini dimulai dengan persiapan, yaitu persiapan guru yang meliputi pelatihan TIK, workshop, dan microteaching; persiapan siswa yang meliputi pelatihan TIK dan persiapan istrumen yang meliputi penyediaan hardware dan software. Kemudian dilakukan pengembangan, yaitu pengkajian kurikulum dan penyusunan materi ekonomi berbasis TIK seperti e-modul. Selanjutnya adalah pelaksanaan, yaitu guru mendampingi siswa belajar ekonomi dengan menggunakan e-modul. Kemudian evaluasi, yaitu penyusunan instrument evaluasi, siswa mengevaluasi pembelajaran ekonomi dengan mengisi instrument, dan guru merevisi pembelajaran ekonomi berdasarkan evaluasi siswa. Terakhir adalah melakukan perbaikan atau revisi dari hasil balikan siswa.

4. Validasi desain

Desain produk yang telah diproduksi, kemudian di evaluasi. Bentuk dari evaluasi produk adalah validasi. Validasi dilakukan oleh ahli materi dan ahli media. Melalui tahap ini diperoleh data kelayakan 
produk dan saran dari ahli.

5. Perbaikan desain. Berdasarakan saran atau masukan dari tenaga ahli, maka desain direvisi sehingga tercipta desain final.

\section{HASIL PENELITIAN DAN PEMBA- HASAN}

Model pembelajaran ekonomi yang dikembangkan dalam penelitian ini adalah model pembelajaran Co-Op Co-Op berbantu teknologi informasi dan komunikasi pada mata pelajaran ekonomi. Tahap-tahap penelitian dan pengembangan ini diadopsi dari teori Borg \& Gall dalam Sugiyono (2010) yang terdiri dari potensi dan masalah, pengumpulan data, desain produk, validasi desain, dan revisi desain. Tahap-tahap yang dilakukan pada penelitian ini sebagai berikut:

\section{Tahap Potensi dan Masalah}

Antusiasme siswa SMA/SMK/MA untuk belajar mata pelajaran ekonomi masih rendah dan partisipasi siswa saat proses pembelajaran sangat rendah dan siswa cenderung hanya menerima materi yang disampaikan guru. Dari sisi guru, kurangnya keterampilan guru dalam mengembangkan pendekatan dan model pembelajaran sehingga fokus pembelajaran hanya terpusat pada guru. Selain itu, sering ditemukan guru-guru ekonomi yang kurang menghubungkan materi pelajaran dengan kenyataan praktis dan keterkaitannya dengan ilmu-ilmu lain dalam mengeksplorasi bahan pembelajaran. Ditambah lagi dengan situasi dan kondisi belajar yang tidak nyaman dan kurang variatif, seperti penggunaan metode ceramah yang kerap digunakan guru, serta minimnya penggunaan media. Oleh karena itu, menurut peneliti perlu dikembangkan model pembelajaran Co-Op Co-Op berbantu teknologi informasi dan komunikasi agar siswa tidak hanya mendapatkan pengetahuan saja, namun dapat membentuk sikap atau emosi yang lebih baik dari sebelumnya, dan memberikan siswa keterampilan dan kreatifitas yang belum siswa dapatkan sebelumnya.

\section{Tahap Pengumpulan Data}

Tahap ini diawali dengan melakukan tinjauan standar isi. Tinjauan standar isi dilakukan dengan cara membuat pemetaan Standar Kompetensi (SK). Berdasarkan tahapan tersebut diperoleh materi yang akan dikembangkan dalam model pembelajaran Co-Op Co-Op berbantu teknologi informasi dan komunikasi. Setelah materi yang dikembangkan sudah ditentukan, maka langkah selanjutnya adalah melakukan studi pustaka.

\section{Tahap Desain Produk}

Model pembelajaran Co-Op Co-Op yang dikembangkan oleh Slavin memiliki berbagai keterbatasan. Pada referensi yang ditulis oleh Slavin, pembelajaran ini (juga model-model pembelajaran yang lain) hanya memuat sintak atau langkah-langkah pembelajaran secara umum. Slavin tidak menyebutkan adanya kondisikondisi sebagai syarat, serta sintaksintak untuk setiap komponen dalam sistem pembelajaran. Oleh karena itu, model ini mencoba untuk memperbaiki model awal dari Slavin, sekaligus membuat integrasi dengan teknologi informasi dan komunikasi. Tahap ini terdiri dari pembuatan kisikisi instrumen penelitian yang menjadi 
kriteria penilaian media pembelajaran ekonomi berbasis TIK.

\section{Tahap Validasi Desain}

Tahap validasi media dilakukan agar model pembelajaran Co-Op Co-Op berbantu teknologi informasi dan komunikasi yang dikembangkan dapat diketahui kelayakannya berdasarkan penilaian ahli materi dan ahli media melalui lembar validasi. Validasi media pembelajaran ekonomi berbasis TIK dilakukan oleh ahli materi yang berkompeten di bidang mata pelajaran ekonomi dan ahli media yang berkompeten di bidang media pembelajaran berbasis TIK. Validasi dilakukan dengan cara mengisi instrument validasi yang didalmnya termuat indikator seperti persiapan, yang meliputi persiapan sarana dan prasarana, persiapan guru, dan persiapan siswa; pengembangan, yang meliputi kajian kurikulum K-13 dan penyususnan materi; pelaksanaan, yang meliputi pendampingan siswa dalam belajar dan evaluasi hasil belajar siswa berbasis TIK; evaluasi, yang meliputi pengembangan instrumen evaluasi dan pelaksanaan evaluasi; dan revisi.
Sebelum melakukan ujicoba, model pembelajaran Co-Op Co-Op berbantu teknologi informasi dan komunikasi yang dikembangkan divalidasi terlebih dahulu oleh ahli materi. Validasi materi dilaksanakan oleh dosen FKIP UKSW yaitu Prof. Dr. Slameto, M.Pd; sedangkan Validasi media dilaksanakan oleh dosen Pendidikan Ekonomi FKIP UKSW yaitu Arief Sadjiarto, SE., M.Pd. Validasi oleh ahli materi dan ahli media bertujuan untuk mendapatkan informasi, kritik, dan saran agar model pembelajaran Co-Op Co-Op berbantu teknologi informasi dan komunikasi yang dikembangkan menjadi produk yang berkualitas secara aspek materi, pembelajaran, dan pengaplikasian.

Hasil validasi tersebut dapat dilihat pada berikut. Skor maksimal dari masing-masing item pernyataan dalam lembar validasi adalah 4 sedangkan skor minimum adalah 1 . Kategori pernyataan positif diberi nilai: sangat tinggi $=4$, tinggi $=3$, sedang $=2$, dan rendah $=1$.

Tabel 1. Hasil Validasi Ahli

\begin{tabular}{clccc}
\hline \multirow{2}{*}{ No } & \multicolumn{1}{c}{ Pernyataan/Pertanyaan } & \multicolumn{3}{c}{ Penilaian } \\
\cline { 2 - 5 } & \multicolumn{1}{c}{ Ahli Materi } & Ahli Media & Rata-rata \\
\hline 1 & $\begin{array}{l}\text { Seberapa tinggi model ini menunjukkan } \\
\text { adanya identifikasi kerangka kunci? }\end{array}$ & 2 & 3 & 2.5 \\
\hline 2 & $\begin{array}{l}\text { Seberapa rinci setiap bagian atau tahapan } \\
\text { dalam kerangka/desain? }\end{array}$ & 2 & 3 & 2.5 \\
\hline 3 & $\begin{array}{l}\text { Seberapa tinggi model ini menunjukkan } \\
\text { adanya seleksi atau memodifikasi bagian } \\
\text { proses yang memang memerlukan } \\
\text { perbaikan? }\end{array}$ & 2 & 2.5 \\
\hline 4 & $\begin{array}{l}\text { Apakah proses/langkah-langkah yang } \\
\text { disusun dalam model ini berkualitas? }\end{array}$ & 2 & 4 & 3 \\
\hline
\end{tabular}




\begin{tabular}{|c|c|c|c|c|}
\hline \multirow{2}{*}{ No } & \multirow{2}{*}{ Pernyataan/Pertanyaan } & \multicolumn{3}{|c|}{ Penilaian } \\
\hline & & Ahli Materi & Ahli Media & Rata-rata \\
\hline 5 & $\begin{array}{l}\text { Seberapa tinggi kadar perbaikan } \\
\text { /peningkatan mutu yang bisa dilakukan } \\
\text { melalui model ini? }\end{array}$ & 2 & 3 & 2.5 \\
\hline \multirow[t]{7}{*}{6} & $\begin{array}{l}\text { Seberapa tinggi kadar model yang } \\
\text { dikembangkan ini ditinjau dari: }\end{array}$ & & & \\
\hline & a. Simple? & 3 & 3 & 3 \\
\hline & b. Applicable? & 2 & 2 & 2 \\
\hline & c. Important? & 3 & 3 & 3 \\
\hline & d. Controllable? & 2 & 2 & 2 \\
\hline & e. Adaptable? & 2 & 3 & 2.5 \\
\hline & f. Communicable? & 2 & 3 & 2.5 \\
\hline \multirow[t]{2}{*}{7} & $\begin{array}{r}\text { Lainnya: a. } \\
\text { b. }\end{array}$ & & & \\
\hline & c. & & & \\
\hline
\end{tabular}

Sumber: Data Primer yang Diolah

Hasil validasi dari ahli materi menunjukkan hasil skor sebesar 24 dengan skor rata-rata: 2.18. Berdasarkan hasil validasi tersebut, dapat diambil kesimpulan bahwa model pembelajaran co-op co-op berbantu teknologi informasi dan komunikasi belum sesuai dengan harapan, maka perlu dilakukan revisi khsusunya pada komponen yang bernilai sedang.

Hasil validasi dari ahli media menunjukkan hasil skor sebesar 30 dengan skor rata-rata: 2.72. Berdasarkan hasil validasi tersebut, dapat diambil kesimpulan bahwa model pembelajaran co-op co-op berbantu teknologi informasi dan komunikasi belum sesuai dengan harapan, maka perlu dilakukan revisi khsusunya pada komponen yang bernilai sedang.

\section{Tahap Revisi Desain}

Produk model yang sudah divalidasi oleh ahli media dan ahli materi, selanjutnya direvisi sesuai dengan saran dan masukan ahli saat proses validasi. Terdapat beberapa bagian pada model pembelajaran yang harus diperbaiki yaitu dari ahli materi, sebagai berikut:
1. Langkah pembelajaran co-op co-op tidak nampak inti belajar yang menunjukkan pemrosesan informasi atau penguasaan kompetensi. Solusi pada revisi ini adalah dalam model perlu dilampirkan Renana Pelaksanaan Pembelajaran (RPP). Dalam model ini, RPP yg dilmapirkan adalah contoh RPP, oleh karena itu guru harus mengubah RPP tersebut sesuai keadan di lapangan.

2. Pemberian makna kurang operasional. Solusi pada revisi ini adalah dalam model yang dikembangkan juga memuat pengantar, langkah-langkah, dan penutup, serta dilampiri dengan RPP dan LKS sebagai kesatuan yang utuh.

3. Pengembangan perlu validasi terlebih dahulu sebelum dilaksanakan. Hal ini telah dilakukan dengan dua orang validator yaitu validator materi dan validator media. Sebelum dilakasnakan, model ini direvisi sesuai masukan validator.

4. Tak jelas kaitan co op co op dan desain produk. Pada Bab pendahulun, hal ini sudah dijelaskan khususnya keterkaitan 
pembelajaran co op co op dengan pembelajaran berbasis TIK.

5. Selain kurikulum dan materi, lembar kerja sangat diperlukan. Solusi pada revisi ini adalah bahwa LKS sudah dibuat sesuai dengan materi per pertemuannya.

Sedangkan revisi dari ahli media adalah perlunya dukungan terhadap kemandirian belajar. Dalam kegiatan di inti pembelajaran, sudah terdapat kegiatan seperti yang seharusnya dilakukan peserta didik yaitu sikap, pengetahuan, dan keterampilan sebagaimana yang dituntut dalam standar proses kurikulum 2013 yang intinya adalah mengarah kepada kemandirian belajar. Berikut rincian gradasi sikap, pengetahuan, dan keterampilan peserta didik:

\begin{tabular}{|c|c|c|}
\hline Sikap & Pengetahuan & Keterampilan \\
\hline Menerima & Mengingat & Mengamati \\
\hline Menjalankan & Memahami & Menanya \\
\hline Menghargai & Menerapkan & Mencoba \\
\hline Menghayati, & Menganalisis & Menalar \\
\hline Mengamalkan & Mengevaluasi & Menyaji \\
\hline- & & Mencipta \\
\hline
\end{tabular}

Hasil revisi berupa produk

final yang telah efektif menurut validator. Produk final ini terdiri dari dua tabel utama, yaitu desain model pembelajaran, dan desain langkah-langkah pelaksanaan sebagai berikut.

Tabel 2. Model Pembelajaran Co-Op Co-Op Berbantu Teknologi Informasi dan Komunikasi (TIK) Pada Mata Pelajaran Ekonomi

\begin{tabular}{|c|c|c|}
\hline No & Langkah & Kegiatan \\
\hline \multirow[t]{4}{*}{1} & Persiapan & \\
\hline & $\begin{array}{l}\text { Persiapan sarana dan } \\
\text { prasarana }\end{array}$ & $\begin{array}{l}\text { Menyediakan teknologi komputer berupa hardware dan } \\
\text { software; teknologi multimedia berupa kamera dan pemutar } \\
\text { video; dan teknologi jaringan komputer berupa LAN dan } \\
\text { modem. }\end{array}$ \\
\hline & Persiapan guru & $\begin{array}{l}\text { Melakukan training atau workshop untuk membekali guru } \\
\text { dengan kemampuan TIK supaya dapat menyelenggarakan } \\
\text { pembelajaran ekonomi berbasis TIK. Trainer dapat berasal dari } \\
\text { guru TIK di sekolah setempat atau dari luar sekolah }\end{array}$ \\
\hline & Persiapan siswa & $\begin{array}{l}\text { Melakukan training atau workshop kepada siswa supaya dapat } \\
\text { mengikuti pembelajaran ekonomi berbasis TIK. Trainer adalah } \\
\text { guru ekonomi yang bersangakutan yang telah ditraining. }\end{array}$ \\
\hline \multirow[t]{3}{*}{2} & Pengembangan & \\
\hline & Kajian kurikulum K-13 & $\begin{array}{l}\text { Operasionaliasi standar isi (KI, KD, dan Indikator) menjadi } \\
\text { materi yang bisa diajarakan lewat media TIK }\end{array}$ \\
\hline & Penyususnan materi & $\begin{array}{l}\text { Mengemas materi yang telah disiapkan ke dalam media } \\
\text { pembelajaran berbasis TIK, misalnya animasi, video, gambar, } \\
\text { dan e-modul. }\end{array}$ \\
\hline \multirow[t]{2}{*}{3} & anaan & \\
\hline & Pendampingan & wa belajar dari instrumen yang telah dikembangkan oleh guru \\
\hline
\end{tabular}




\begin{tabular}{|c|c|c|}
\hline No & Langkah & Kegiatan \\
\hline & dalam belajar & dan guru mengawasi siswa dalam proses pembelajaran \\
\hline & $\begin{array}{l}\text { Evaluasi hasil belajar } \\
\text { siswa berbasis TIK }\end{array}$ & $\begin{array}{l}\text { Siswa mengerjakan test melalui fasilitas TIK yang telah } \\
\text { disediakan dan guru memantau jalannya sistem. }\end{array}$ \\
\hline \multirow[t]{3}{*}{4} & Evaluasi & \\
\hline & $\begin{array}{l}\text { Pengembangan } \\
\text { instrument evaluasi }\end{array}$ & $\begin{array}{l}\text { Guru membuat instrumen yang berisi balikan dari siswa terkait } \\
\text { keberlangsungan pembelajaran. }\end{array}$ \\
\hline & Pelaksanaan evaluasi & $\begin{array}{l}\text { Siswa memberikan balikan dengan mengisi instrumen yang } \\
\text { telah dibuat guru. Sedangkan guru mempelajari balikan } \\
\text { instrumen dari siswa }\end{array}$ \\
\hline 5 & Revisi & $\begin{array}{l}\text { Berdasarakan hasil evaluasi, guru merevisi media pembelajaran } \\
\text { yang telah digunakan oleh siswa }\end{array}$ \\
\hline
\end{tabular}

Supaya semua keterbatasan yang dihadapi dapat terakomodir dengan baik, maka model pembelajaran ini dikembangkan dengan lima langkah kegiatan. Kelima langkah tersebut adalah persiapan, pengembangan, pelaksanaan, evaluasi, dan revisi. Setiap langkah berisikan kegiatankegiatan yang harus dilakukan baik oleh guru, siswa, maupun instrumen pembelajaran yang lain. Berikut rincian dari kelima langkah yang dimaksud.

Kegiatan-kegiatan pada tahap pelaksanaan berisikan sintak yang merupakan pengembangan dari sintak Co-Op Co-Op yang telah dibangun oleh Slavin. Berikut langkah-langkah pembelajaran Co-Op Co-Op yang telah dikembangkan:

Tabel 3 Langkah-Langkah Pembelajaran Co-Op Co-Op Berbantuan TIK

\begin{tabular}{|c|c|c|c|}
\hline Langkah & Aktivitas Guru & Aktivitas Siswa & TIK \\
\hline $\begin{array}{l}\text { Langkah } 1 \\
\text { Diskusi Kelas } \\
\text { Terpusat pada } \\
\text { Siswa. }\end{array}$ & $\begin{array}{l}\text { - Memotivasi siswa } \\
\text { untuk menemukan dan } \\
\text { mengekspresikan } \\
\text { ketertarikan mereka } \\
\text { sendiri terhadap } \\
\text { subjek yang akan } \\
\text { dicakupi. } \\
\text { - Membiarkan siswa } \\
\text { untuk diskusi kelas } \\
\text { yang terpusat pada } \\
\text { siswa itu sendiri. }\end{array}$ & $\begin{array}{l}\text { Menemukan ide/ } \\
\text { materi yang akan di } \\
\text { pelajari. }\end{array}$ & $\begin{array}{l}\text { Materi atau ide yang } \\
\text { akan dipelajari } \\
\text { disajikan dalam blog } \\
\text { milik guru }\end{array}$ \\
\hline $\begin{array}{c}\text { Langkah } 2 \\
\text { Pembentukan } \\
\text { tim }\end{array}$ & $\begin{array}{l}\text { - Membagi siswa dalam } \\
\text { tim heterogen yang } \\
\text { terdiri dari empat } \\
\text { sampai lima anggota. } \\
\text { - Menginformasikan } \\
\text { kepada siswa } \\
\text { bagaimana } \\
\text { menemukan ide } \\
\text { pokok/tujuan } \\
\text { pembelajaran yang } \\
\text { hendak dicapai. }\end{array}$ & $\begin{array}{l}\text { - Membentuk } \\
\text { kelompok. } \\
\text { - Memperhatikan } \\
\text { penjelasan guru. }\end{array}$ & \\
\hline
\end{tabular}




\begin{tabular}{|c|c|c|c|}
\hline Langkah & Aktivitas Guru & Aktivitas Siswa & TIK \\
\hline $\begin{array}{c}\text { Langkah } 3 \\
\text { Seleksi topik tim }\end{array}$ & $\begin{array}{l}\text { Mendorong para siswa } \\
\text { untuk mendiskusikan } \\
\text { berbagai macam topik di } \\
\text { antara mereka sendiri. }\end{array}$ & $\begin{array}{l}\text { Mendiskusikan } \\
\text { berbagai macam } \\
\text { topik. }\end{array}$ & $\begin{array}{l}\text { Siswa dapat } \\
\text { mencari } \\
\text { pengembangan } \\
\text { topik dari internet }\end{array}$ \\
\hline $\begin{array}{c}\text { Langkah } 4 \\
\text { Pemilihan Topik } \\
\text { Kecil }\end{array}$ & $\begin{array}{l}\text { Memberikan tugas kepada } \\
\text { siswa yang berkaitan } \\
\text { dengan topik kecil mereka } \\
\text { atau dengan tim } \\
\text { membagi topiknya untuk } \\
\text { membuat pembagian tugas } \\
\text { di antara anggota tim }\end{array}$ & $\begin{array}{l}\text { Memperhatikan } \\
\text { penjelasan guru dan } \\
\text { pembagian tugas tim. }\end{array}$ & $\begin{array}{l}\text { Siswa menulis } \\
\text { topik-topik kecil } \\
\text { yang akan } \\
\text { dipelajari, dan } \\
\text { langsung di share ke } \\
\text { kelompok lain }\end{array}$ \\
\hline $\begin{array}{c}\text { Langkah } 5 \\
\text { Persiapan Topik } \\
\text { Kecil }\end{array}$ & $\begin{array}{l}\text { Mengamati siswa } \\
\text { dalam bekerja individual } \\
\text { untuk kontribusi dalam } \\
\text { tim. }\end{array}$ & $\begin{array}{l}\text { Belajar sendiri } \\
\text { tentang topik kecil } \\
\text { dari tim. }\end{array}$ & $\begin{array}{l}\text { Siswa } \\
\text { memanfaatkan TIK } \\
\text { untuk belajar }\end{array}$ \\
\hline $\begin{array}{c}\text { Langkah } 6 \\
\text { Presentasi Topik } \\
\text { Kecil }\end{array}$ & $\begin{array}{l}\text { Mengamati siswa } \\
\text { dalam mempresentasikan } \\
\text { pemahamannya dalam tim } \\
\text { sendiri. }\end{array}$ & $\begin{array}{l}\text { Mempresentasikan } \\
\text { pemahamannya } \\
\text { dalam tim sendiri. }\end{array}$ & \\
\hline $\begin{array}{c}\text { Langkah } 7 \\
\text { Persiapan } \\
\text { Presentasi Tim }\end{array}$ & $\begin{array}{l}\text { Mendorong para siswa } \\
\text { untuk memadukan semua } \\
\text { topik kecil dalam } \\
\text { presentasi tim. }\end{array}$ & $\begin{array}{l}\text { Memadukan semua } \\
\text { topik kecil dalam } \\
\text { tim. }\end{array}$ & $\begin{array}{l}\text { Siswa membuat } \\
\text { peta perpaduan } \\
\text { dengan program } \\
\text { mind map }\end{array}$ \\
\hline $\begin{array}{c}\text { Langkah } 8 \\
\text { Presentasi Tim }\end{array}$ & $\begin{array}{ll}\text { - } & \text { Mengatur waktu } \\
\text { presentasi tim. } \\
\text { - } \\
\text { Membuka tanya jawab } \\
\text { siswa kepada tim yang } \\
\text { selesai presentasi. }\end{array}$ & $\begin{array}{ll}\text { - Siswa dan tim } \\
\text { melakukan } \\
\text { presentasi di } \\
\text { depan kelas. } \\
\text { - } \text { Menanyakan dan } \\
\text { menjawab } \\
\text { pertanyaan- } \\
\text { pertanyaan } \\
\end{array}$ & $\begin{array}{l}\text { Siswa mengupload } \\
\text { hasil belajarnya di } \\
\text { blog, lalu } \\
\text { mempresentasikan, } \\
\text { siswa lain menyimak } \\
\text { di blog presenter }\end{array}$ \\
\hline $\begin{array}{c}\text { Langkah } 9 \\
\text { Evaluasi }\end{array}$ & $\begin{array}{l}\text { Membiarkan siswa } \\
\text { pada saat presentasi } \\
\text { tim dievaluasi oleh } \\
\text { kelas. } \\
\text { - Guru bersama dengan } \\
\text { siswa melakukan } \\
\text { refleksi. }\end{array}$ & $\begin{array}{l}\text { Mengevaluasi } \\
\text { pembelajaran }\end{array}$ & $\begin{array}{l}\text { Evaluasi dilakukan } \\
\text { dengan } \\
\text { mengerjakan tes } \\
\text { berbasis computer }\end{array}$ \\
\hline
\end{tabular}

\section{KESIMPULAN}

Berdasarkan hasil penelitian yang telah diperoleh, disimpulkan bahwa telah dikembangkan model pembelajaran co-co coco berbantuan TIK pada mata pelajaran ekonomi. Model yang dikembangkan ter-diri dari lima langkah utama, yaitu tahap persiapan, pengembangan, pelaksanaan, evaluasi dan revisi. Khusus pada tahap pelaksanaan, model co-op co-op yang dikembangkan terdiri dari sembilan langkah yang dilaksanakan dengan bantuan TIK.

Model pembelajaran ini diduga mampu mengefektifkan proses pembelajaran, dimana peserta didik dan guru terbantu dengan adanya fasilitas TIK. Hal ini sejalan dengan penilaian para validator bahwa model 
ini diduga efektif untuk diimplentasikan dalam pembelajaran ekonomi.

Karena penelitian ini sampai pada tahap revisi, maka disarankan kepada peneliti selanjutnya untuk menguji coba model ini secara empiris. Tahapan uji coba mengacu pada tahapan pengembangan model dari Borg and Gall, dan dapat dilakukan dengan penelitian tindakan (action research) maupun penelitian eksperimen.

\section{DAFTAR PUSTAKA}

Abdullah. 1992. Materi Pokok Pendidikan IPS-2: Buku 1, Modul 1, Jakarta: Departemen Pendidikan dan Kebudayaan, PPPG Tertulis.

Anggia, Dewi,. 2015. Implementasi Multimedia Interaktif Dalam Pembelajaran Ekonomi di Sekolah. Skripsi, Jurusan Pendidikan Ekonomi FKIP Universitas Muhammadiyah Metro.

Budimansyah, Dasim. 2003. Model Pembelajaran Ekonomi. Bandung: Genesindo.

Celebic \& Dario. 2011. Basic Concepts of Information and Communication Technology. Zagreb: Infokatedra, Center For Adult Education.

Daniel, John. 2002. Information and Communication Technology in Education. Russia: Division of Higher Education UNESCO.

Ismaniati, Christina. 2010. Penggunaan Teknologi Informasi Dan Komunikasi Dalam Peningkatan Kualitas Pembelajaran. Yogyakarta.

Ismaya, Sujana 2007. Kamus Besar Ekonomi. Bandung: Pustaka Grafika.

Kertiyasa, Ahcmad Halim Indra. 2013. Permasalahan Pembelajaran
Ekonomi dan Solusi Pemecahannya (Studi Kasus Pada Guru-Guru Ekonomi di SMA Negeri Kota Mojokerto). Skripsi, Jurusan Ekonomi Pembangunan Program Studi Pendidikan Ekonomi Fakultas Ekonomi Universitas Negeri Malang.

Krisnadi. 2009. Rancangan Materi Pembelajaran Berbasis ICT. Disajikan dalam Workshop Pengembangan Materi Pembelajaran Berbasis ICT di FMIPA UNY pada tanggal 6 Agustus 2013.

Laudon. 2007. Essentials of Management Information Systems. New Jersey: Prentice-Hall, Inc.

Novia, Gita Norani. 2012. Implementasi Metode Pembelajaran Team Quiz Bervariasi Untuk Meningkatkan Motivasi dan Hasil Belajar Ekonomi Pada Siswa Kelas VIIIC SMP Muhammadiyah 2 Surakarta Tahun Ajaran 2011/2012. Skripsi, Jurusan Akuntasi Fakultas Keguruan dan Ilmu Pendidikan Universitas Muhammadiyah Surakarta.

Republik Indonesia. 2003. Undang-undang No. 20 Tahun 2003 tentang Sistem Pendidikan Nasional.

Republik Indonesia. 2003. Undang-undang No. 21 Tahun 2003 tentang Standar Isi/Standar Kompetensi Dasar SMA

Republik Indonesia. 2003. Undang-undang No. 22 Tahun 2003 tentang Standar Isi Untuk Satuan Pendidikan Dasar dan Menengah

Sholikha, Siti Mazilatus. 2015. Penerapan Teknologi Informasi Dalam Pendekatan Saintifik Pada Mata Pelajaran Ekonomi. Surabaya: 
Fakultas Ekonomi Universitas Negeri Surabaya.

Siahaan, Sudirnan. 2009. Pemanfaatan Teknologi Informasi dan Komunikasi dalam Pembelajaran. Jakarta: Pustekkomdiknas.

Slavin. 2009. Cooperatiive Learning: Riset dan Praktik. Bandung: Nusamedia.
Sugiyono. 2010. Metode Penelitian Kuantitatif, Kualitatif dan $R \& D$. Bandung: Alfabeta.

Sukwiaty dkk. 2009. Ekonomi 2 SMA/MA Kelas XI. Jakarta: Yudhistira.

Suryani, Nunuk. 2015. Pengembangan Media Pembelajaran Berbasis IT. Pascasarjana Program Studi Teknologi Pendidikan Universitas Sebelas Maret. 